DOI: $10.19195 / 0137-1150.163 .4$

\author{
MAGDALENA DĄBROWSKA \\ Uniwersytet Warszawski, Polska \\ m.dabrowska@uw.edu.pl
}

\title{
Młodość i starość (według) Nikołaja Karamzina
}

O młodości i starości Nikołaj Karamzin wypowiadał się w utworach literackich i publicystycznych oraz w korespondencji, rzadko jednak — bodaj tylko w nieukończonym Rycerzu naszych czasów, poświęconym wczesnym latom życia człowieka - wysuwając te tematy na plan pierwszy. Przeciętnie rozeznany w twórczości pisarza czytelnik przypomni sobie co najwyżej bohaterki Biednej Lizy, ,piękną, miłą Lizę i staruszkę, jej matkę"1, lepiej zorientowany — znający genezę programowej rosyjskiej opowieści sentymentalnej — wskaże na podobieństwo między nimi a epizodycznymi postaciami Listów podróżnika rosyjskiego, sześćdziesięcioletnią żebraczką, po śmierci córki wygnaną z domu na wsi i zamieszkującą opuszczony zamek w Lasku Bulońskim². Już tylko biografowie Karamzina będą w stanie przywołać rozsiane po jego korespondencji wzmianki o starcach Monteskiuszu ${ }^{3}, \mathrm{Klopstocku}^{4}$ i Lavaterze, ,gasnącym niczym dopalająca się świeczka"5, o „starości na dworze”6, wreszcie o tym, że jego własne życie ma się ku końcowi ${ }^{7}$. Te ostatnie słowa zapisał Karamzin w 1817 roku, mając przed sobą jeszcze dziewięć lat życia. Badacze dużo chętniej odtwarzają przy

${ }^{1}$ Н.М. Карамзин, Бедная Лиза, [w:] idem, Записки старого московского жителя. Избранная проза, Москва 1988, s. 42. Tu i dalej, o ile nie podano inaczej, przekład własny M.D.

2 Zob. Н.M. Карамзин, Письма русского путешественника, Ленинград 1984, s. 242-243.

${ }^{3}$ Н.М. Карамзин, Избранные статьи и письма, red. А.Ф. Смирнов, Москва 1982, s. 207 (list do P.A. Wiaziemskiego z nagłówkiem „Carskie Sioło, 3 czerwca 1819”).

${ }^{4}$ Письма Н.М. Карамзина к И.И. Дмитриеву, red. Я.К. Грот, П.П. Пекарский, СанктПетербург 1866, s. 67 („Moskwa, 4 czerwca 1796 r.”).

5 Ibidem.

${ }^{6}$ Н.М. Карамзин, Избранные статьи и письма..., s. 215 (list do P.A. Wiaziemskiego z nagłówkiem „S.-Petersburg, 2 grudnia 1822”).

${ }^{7}$ Ibidem, s. 238 (list do W.M. Karamzina z nagłówkiem „Carskie Sioło, 22 maja 1817”). 
tym wczesny okres życia pisarza oraz jego wizję dzieciństwa i młodości niż okres schyłkowy, a także stosunek do starości, mimo że więcej zachowanych świadectw — osób z otoczenia Karamzina i jego samego — dotyczy właśnie schyłku życia ${ }^{8}$. Za przykład może służyć periodyzacja życia i twórczości zaproponowana przez Jewgienija Osietrowa w powieści-studium Trzy życia Karamzina: okres pierwszy został określony hasłowo jako „dzieciństwo, Wołga, młodość, wiersze, miłość, marzenia literackie, przekłady, Czyste Prudy, »życie serca«, opowieści sentymentalne, »Moskowskij żurnał«, »Aonidy«, [...] Listy podróżnika rosyjskiego", drugi przyniósł Historię państwa rosyjskiego, trzecim stały się... „pośmiertne losy [...] pisarza" ". O sławie pośmiertnej wspominał zresztą sam Karamzin w kontekście Historii państwa rosyjskiego: „chciałbym wziąć się za pracę najważniejszą: za historię rosyjską, aby pozostawić po sobie dla ojczyzny niezgorszy pomnik" pisał w 1803 roku do starszego brata Wasilija ${ }^{10}$. Schyłkiem życia pisarza zajmował się szerzej tylko Jurij Łotman, podsumowujący je w następujących słowach:

ostatnie dziesięć lat życia upłynęło Karamzinowi [...] niczym w sielance: kochająca rodzina, krąg przyjaciół, praca, szacunek, [...] dostatek materialny — owoc nieprzerwanej pracy; mimo to, gdy czyta się [...] dokumenty, listy, wspomnienia, zaczyna ogarniać poczucie grozy [...]: pod cienką warstewką życiowej pomyślności skrywa się mrok ${ }^{11}$.

Jak wynika z tej wstępnej charakterystyki, można mówić zarówno o młodości i starości samego Karamzina, jak i młodości i starości według Karamzina, a więc skupić się na porządku biograficznym lub kreacji artystycznej, ściśle zresztą dopełniających się wzajemnie.

Na potrzebę rozdzielenia tych dwóch porządków wskazywał - w kontekście szerszym niż problem młodości i starości - Jurij Łotman, porównując młodego Karamzina z narratorem Listów podróżnika rosyjskiego: „na stronach

${ }^{8}$ Dokonując takiego wyboru, badacze niejako „wpisują się” w sposób myślenia samych przedstawicieli XVIII wieku, w którym, jak wyraził się Neil Postman, „wynaleziono dzieciństwo”, dostrzegając w nim nie tylko „konieczność biologiczną”, ale także „konstrukt społeczny” (N. Postman, W stronę XVIII stulecia. Jak przeszłość może doskonalić nasza przyszłość, tłum. R. Frąc, Warszawa 2001, s. 127). Starość nie musiała aż tyle czekać na „odkrycie”, gdyż w tych dwóch kontekstach rozpatrywano ją już w starożytności. Do nieco innego wniosku w kwestii czasu „odkrycia” dzieciństwa i starości w Europie doszedł natomiast Jean-Pierre Bois: „wejście starego człowieka do rodziny, któremu towarzyszyło odkrycie dziadków i babek, w naturalny sposób uzupełniające odkrycie wczesnego dzieciństwa - wszystko to zaczynało być ledwo widoczne między końcem XVII wieku a początkiem XVIII; była to pauza, która jawi się jako okres przejściowy między dwoma długimi okresami historycznymi — okresem historii europejskiego społeczeństwa bez starości, które swoich starych ludzi uważało jedynie za dorosłych w późnej fazie dojrzałości, i okresem historii społeczeństwa europejskiego, w którym starość istnieje..." J.-P. Bois, Historia starości. Od Montaigne'a do pierwszych emerytur, tłum. K. Marczewska, Warszawa 1996, s. 133).

${ }^{9}$ Е. Осетров, Три жизни Карамзина. Роман-исследование, Москва 1989, s. 12.

${ }^{10}$ Н.М. Карамзин, Избранные статьи и письма..., s. 222 („Swirłowo, 6 czerwca 1803 r.”).

11 Ю.М. Лотман, Сотворение Карамзина, [w:] idem, Карамзин. Сотворение Карамзина. Статьи и исследования 1957-1990. Заметки и рещензии, Санкт-Петербург 1997, s. 298. 
książki podróżuje miły, żądny wiedzy, ale dość lekkomyślny młody człowiek, z żywymi, ale płytkimi zainteresowaniami”, gdy tymczasem w rzeczywistości wyruszał w podróż człowiek dojrzały, odznaczający się „,samodzielnością zainteresowań i sądów"12. Jednocześnie jednak należy mieć świadomość autobiograficznego podłoża części twórczości Karamzina, przy czym nie dotyczy to wyłącznie Listów podróżnika rosyjskiego. Oświeceniowym traktatem filozoficznym o szczęściu Grigorij Makogonienko nazwał Melodora do Filaleta i Filaleta do Melodora (1795), Rozmowę o szczęściu... (1797) i O najszczęśliwszym okresie życia (1803), zaznaczając, że łączy je autobiograficzność: jeśli potraktować je jako całość, okaże się, że odzwierciedlają one ewolucję poglądów pisarza w latach $1793-1803^{13}$. Te właśnie utwory oraz Rycerz naszych czasów tworzą główną część materiału badawczego przeznaczonego do omówienia w drugim z wymienionych kluczy.

„Ojczyzną moją jest gubernia symbirska” — napisał Iwan Dmitrijew ${ }^{14}$, a pod słowami tymi mógłby podpisać się również autor Listów podróżnika rosyjskiego. Urodzony w 1766 roku w rodzinie właściciela majątków ziemskich w guberniach symbirskiej i orenburskiej Karamzin pobierał naukę początkowo w domu, później krótko w Symbirsku, wreszcie — w latach 1780-1783 — szkole J. Schadena w Moskwie; w latach 1783-1784 służył w Pułku Prieobrażenskim w Petersburgu. Właśnie Dmitrijew pozostawił po sobie najobszerniejszą, zdaniem Władimira Murawiowa, wzmiankę o dzieciństwie Karamzina: po raz pierwszy ujrzał go w 1770 roku trzymanego za rękę przez „rosyjską nianię” na weselu w Symbirsku; z tego, że sam Dmitrijew przebywał na uroczystości pod opieką nauczyciela-Francuza, Murawiow wywnioskował, iż obaj byli wychowywani według różnych zasad ${ }^{15}$. Ich przyjaźń przetrwa wiele lat. Listom Karamzina do Dmitrijewa (zwłaszcza z lat 1818-182616) - wysoko cenionym przez Piotra Wiaziemskiego jako „wyznanie” autora Historii państwa rosyjskiego ${ }^{17}$ — zawdzięczamy wiedzę o schyłku jego życia: odzwierciedlają one etapy narastania w nim świadomości zbliżania się śmierci oraz stosunek do starości, swoistą „,filozofię starości”. W spuściźnie epistolograficznej Karamzina warto zwrócić uwagę oprócz tego na

12 Ibidem, s. 28.

13 Г.П. Макогоненко, Публицистика, [w:] Н.М. Карамзин, Сочинения в двух томах, t. 2. Критика. Публицистика. Главы из „Истории Государства Российского”, Ленинград 1984, s. 406.

${ }^{14}$ И.И. Дмитриев, Взгляд на мою жизнь, Москва 1866, s. 11.

15 В. Муравьев, Николай Карамзин, Москва 2005, s. 13.

16 Pierwszy etap wymiany listów między nimi przypadł na lata 1787-1817.

17 П.А. Вяземский, О письмах Карамзина, [w:] Карамзин: pro et contra. Личность и творчество Н.М. Карамзина в оиенке русских писателей, критиков, исследователей. Антология, red. Д.К. Бурлака, Санкт-Петербург 2006, s. 85. Można dodać, że takiej roli nie odegrała autobiografia Karamzina, opracowana w 1805 lub 1806 roku na potrzeby słownika pisarzy rosyjskich przygotowywanego przez Jewfimija Bołchowitinowa. 
listy do szwajcarskiego myśliciela Johanna Kaspara Lavatera, rzucające światło na młodość pisarza ${ }^{18}$.

Korespondencja z Lavaterem obejmuje okres od 14 sierpnia 1786 roku do grudnia roku 1790. Wspomnienie młodości, rozpoczynające się od słów: „kiedy byłem jeszcze chłopcem", zawiera list pierwszy. Dwudziestoletni Karamzin podsumowuje w nim dotychczasowe życie, wskazując na momenty zwrotne i osoby, które wpłynęły na podejmowane wtedy przez niego decyzje. Pierwszym z nich był nauczyciel niemieckiego, drugim — pewien ,szacowny mąż”, czyli Iwan Turgieniew, z którym przyszły historiograf opuścił Symbirsk ${ }^{19}$. Obaj skłonili go do kontynuowania nauki, zagłębienia się w książki, drugi ponadto odciągnął go od kart, głównej rozrywki towarzystwa salonowego. „Znów zająłem się książkami i poczułem w duszy mojej [...] ciszę; taki też tryb życia prowadzę teraz..." stwierdza na zakończenie Karamzin ${ }^{20}$. Jak zauważa A.F. Smirnow, korespondencja Karamzina z Lavaterem, z którym pisarz rosyjski spotkał się osobiście w czasie podróży europejskiej i odnotował ten fakt w Listach podróżnika rosyjskiego, odzwierciedla jego rozterki egzystencjalne, poszukiwania celu i sensu życia ${ }^{21}$.

Nieukończona powieść psychologiczna Rycerz naszych czasów rozpatrywana jest zwykle w kontekście recepcji twórczości Jeana-Jacques'a Rousseau w Rosji. Tak ujmował tę kwestię Jurij Łotman: w Rycerzu naszych czasów twórca „postanowił opisać historię swojego życia, sytuując siebie nie względem normy [...], lecz przeciwnie, przedstawiając jednostkę ludzką jako splot [...] odstępstw od niej; [...] polemika z Rousseau łączyła się tu z kontynuowaniem jego tradycji i bezpośrednimi nawiązaniami do niej” ${ }^{22}$. To, co Łotman nazwał „odstępstwami od normy”, J.N. Kupriejanowa określiła jako „przeciwności serca”, podkreślając, że Rycerz naszych czasów zapisał się w dziejach literatury rosyjskiej jako pierwsza próba stworzenia rozbudowanego portretu psychologicznego, podjęta w dużym stopniu pod wpływem Wyznań Rousseau ${ }^{23}$. Wracając zaś do kwestii polemiki Karamzina z Rousseau, można powtórzyć za Natalią Koczetkową, rów-

18 Переписка Карамзина с Лафатером сообщена доктором Ф. Вальдманом, red. Я. Грот, Санкт-Петербург 1893.

19 Zob. А.Ф. Смирнов, Из писем к Лафатеру 1786-1790 г2., [w:] Н.М. Карамзин, Избранные статьи и письма..., s. 323. Wcześniej w „,szacownym mężu” dopatrywano się raczej Iwana Dmitrijewa; zob. Переписка Карамзина с Лафатером..., s. 6 (przypis).

${ }^{20}$ Переписка Карамзина с Лафатером..., s. 6.

21 А.Ф. Смирнов, Из писем к Лафатеру..., s. 322.

22 Ю.М. Лотман, Руссо и русская культура ХVIII века, [w:] Эпоха Просвещения. Из истории международных связей русской литературы, red. М.П. Алексеев, Ленинград 1967, s. 277.

23 Е.Н. Купреянова, Русский роман первой четверти ХІХ века. От сентиментальной повести к роману, [w:] История русского романа в двух томах, red. А.С. Бушмин, Б.П. Городецкий, Н.И. Пруцков, Г.М. Фридлендер, t. 1, Москва 1962, s. 73-74. Por. С.Л. Скопкарёва, Структура житийного повествования в произведении Н.М. Карамзина „Рыцарь нашего времени", [w:] Н.М. Карамзин: писатель, ученый, публицист, red. В.В. Молчановский, С.Н. Травников, Москва 2012, s. 102-104. 
nież badającą Rycerza naszych czasów w kontekście Wyznań, że pisarz rosyjski wystąpił przeciw głośnej tezie filozofa francuskiego o wrodzonej dobroci człowieka poprzez przywołanie teorii „czystej karty” („niezapisanej tablicy”) Johna Locke’a. Opowieść o pierwszych latach życia Leona, nastawiona bardziej na zapis jego świata wewnętrznego (np. skłonność do marzycielstwa i melancholii) niż warstwy zdarzeniowej (np. śmierć matki czy przebieg edukacji), może być odczytywana jednak również na wiele innych sposobów. Zastosowanie wobec niej „klucza” biograficznego, podpowiedzianego zresztą przez samego Karamzina, który nazwał ją nie tylko „historią [...] przyjaciela”, lecz także „powieścią opartą na wspomnieniach młodości, którym Autor oddawał się podczas choroby" ${ }^{24}$, prowadzi do stwierdzenia podobieństw (rzadziej różnic) w postawie i drodze życiowej bohaterów Rycerza naszych czasów oraz samego Karamzina czy osób z jego otoczenia. Badacze zauważają więc, że „wszystko, co opowiedziano o ojcu Leona, odpowiada biografii Michaiła Jegorowicza [tj. ojca Nikołaja Karamzina - M.D.]” ${ }^{25}$, „prezentując krąg lektur Leona, Karamzin opierał się na własnym doświadczeniu" ${ }^{26}$, ale również, że „bohater [Leon — M.D.] ma [...] siedem lat, gdy umiera jego matka, podczas gdy Karamzin stracił matkę w niemowlęctwie"27. Rycerz naszych czasów nie jest bowiem, jak pisze Koczetkowa, „dokumentem, lecz powieścią, zapewniającą autorowi prawo do przemilczeń i ubarwień"28; co więcej, jest to powieść w znacznym stopniu zabarwiona ironicznie, w czym należy doszukiwać się wpływu Laurence'a Sterne'a ${ }^{29}$. W tym ostatnim kontekście można dodać, że ślady zainteresowania prozą Sterne’a znajdujemy w różnych miejscach pisma „Wiestnik Jewropy”, w którym ukazała się też opowieść o Leonie ${ }^{30}$.

Na stan zdrowia Karamzin skarżył się w listach do różnych osób już pod koniec XVIII wieku. W lutym 1799 roku pisał z Moskwy do Iwana Dmitrijewa, że od trzech tygodni jest chory: blednie, chudnie, z trudem wchodzi na niski ganek; ma nadzieję jednak, że poprawa nastąpi wiosną, na którą liczy bardziej niż na le-

${ }^{24}$ Pierwsze określenie pojawia się we wstępie do Rycerza naszych czasów, drugie — w przedmowie redakcyjnej do trzeciego „odcinka” utworu (zaczynającego się od rozdziału IX) w czasopiśmie „Wiestnik Jewropy”. [Н.М. Карамзин], Рыцарь нашего времени, „Вестник Европы” 1803, июль, $\mathrm{nr}$ 14, s. 121.

25 В. Муравьев, Николай Карамзин..., s. 10.

${ }^{26}$ Н.Д. Кочеткова, Герой русского сентиментализма. 1. Чтение в жизни ,чувствительного” героя, „XVIII век”, t. 14. Русская литература XVIII-начала ХІХ в. в общественно-культурном контексте, Ленинград 1983, s. 136-137.

${ }^{27}$ Н.Д. Кочеткова, „Исповедь” в русской литературе кониа XVIII в., [w:] На путях к романтизму, red. Ф.Я. Прийма, Ленинград 1984, s. 99.

${ }^{28}$ Ibidem.

29 Ibidem.

${ }^{30} \mathrm{Np.}$ История Лафлёра, Стернова слуги, „Вестник Европы” 1802, июль, nr 13, s. $12-$ 21. Rycerz naszych czasów został zamieszczony w 1802 roku w numerach 13 i 18 oraz we wspomnianym numerze 14 z 1803 roku. 
karzy $^{31}$. Poprawa najwyraźniej nie nastąpiła, skoro w październiku tego samego roku pisał w jeszcze bardziej dramatycznym tonie: „kwiaty życia coraz bardziej dla mnie więdną; pragnę tylko jednego: umrzeć spokojnie"32. I zapewne nie był to zwykły chwyt artystyczny polegający na paralelnym zestawianiu stanu natury i sytuacji człowieka. W 1803 roku w liście do brata Wasilija stwierdzał co prawda, że „nie może [...] uskarżać się na swoje zdrowie”, ale jednocześnie wspomniał o słabnącym wzroku, sugerując, iż jest to powód jego rezygnacji z wydawania czasopisma „Wiestnik Jewropy” i zajęcia się przygotowaniem Historii państwa rosyjskiego („wezmę się za historię, która nie wymaga szybkiej pracy”) ${ }^{33}$. „Czas jest dla mnie cenny: zbliżam się do starości; kilka lat mogę jeszcze pisać, pięć, sześć, jeśli Bóg pozwoli" - zwierzał się Dmitrijewowi w grudniu 1812 roku, zapowiadając swój wyjazd do Petersburga, gdzie znajdzie lepsze warunki do pra$\mathrm{cy}^{34}$. Od tego czasu aż do śmierci temat starości będzie pojawiać się w korespondencji Karamzina stale, zwykle jednak w kontekście pogodzenia się z nią. ,,Stary dla młodych i [...] starych”35, cieszy się z każdego dnia spędzonego „z rodziną, przyjacielem, książkami”"36, jednocześnie żegnając się na odległość z rodzinnymi okolicami, „Symbirskiem, Wołgą, Swijagą”37. W ostatnich listach Karamzina przewija się myśl, że bez pogodzenia się ze śmiercią nie jest możliwe docenienie przyjemności życia. „Aby poczuć całą słodycz życia, należy polubić i śmierć” — stwierdza (i jak wielokrotnie stwierdzano to już od starożytności), dodając, że niezbyt troszczy się o sławę pośmiertną jako pisarza, mimo iż pisarstwu poświęcił życie ${ }^{38}$. Z przytoczoną wypowiedzią korespondują słowa skierowane przez niego do Jelizawiety Aleksiejewny: ,życie jest krótkie, dlatego też bardziej czujemy jego przyjemności" 39 . Pod wpływem lekarzy i Iwana Dmitrijewa (od pewnego czasu również skarżącego się na „przedwczesną starość’40) Karamzin zaczął snuć plany podróży dla poratowania zdrowia — nad morze, pod „,niebo Italii’"4l; lekarstwem na starość ma się stać zmiana miejsca, lekarstwem bardziej działającym jednak na psychikę niż na ciało. Zbawienny wpływ na psychikę miał polegać na wyprowadzeniu ze stanu znużenia życiem. W podróż na południe Europy nie dane było już Karamzinowi wyruszyć. Na przebieg ostatniej choroby pisarza rzucają światło również listy jego córek, Sofii i Jekatieriny. Odnotowują one

${ }^{31}$ Zob. Письма Н.М. Карамзина к И.И. Дмитриеву..., s. 109.

32 Ibidem, s. 113.

${ }^{33}$ Н.М. Карамзин, Избранные статьи и письма..., s. 222 (list z nagłówkiem „Moskwa, 13 października 1803 ”).

${ }^{34}$ Письма Н.М. Карамзина к И.И. Дмитриеву..., s. 169.

35 Ibidem, s. 275 („,Sankt-Petersburg, 3 listopada 1819”).

${ }^{36}$ Ibidem, s. 248 („Carskie Sioło, 11 września 1818”).

37 Ibidem, s. 398 („Carskie Sioło, 9 lipca 1825”).

38 Ibidem, s. 409 („Carskie Sioło, 22 października 1825”).

39 Неизданные сочинения и переписка Николая Михайловича Карамзина, cz. 1, СанктПетербург 1862, s. 79 (list bez oznaczenia roku).

40 Письма Н.М. Карамзина к И.И. Дмитриеву..., s. 154 („Ostafiewo, 9 sierpnia 1811”).

${ }^{41}$ Ibidem, s. 419-420 („Sankt-Petersburg, 16 kwietnia 1826”). 
zarówno stan fizyczny chorego, jak i jego nastrój: piszą o spokojnym śnie, braku apetytu, zmianie lekarza, prośbach o czytanie gazet. Wtedy pisarz był w stanie już tylko dopisywać krótkie zdania do ich listów: w marcu 1826 roku stwierdził, że „słabnie niczym niemowlę ${ }^{42}$. Do przytoczonego wcześniej Łotmanowskiego podsumowania ostatnich dziesięciu lat życia twórcy Historii państwa rosyjskiego warto dodać jeszcze jedną opinię tego samego badacza: „Karamzin był człowiekiem pracowitym i cenił swoje zdrowie jako warunek intensywnej pracy"43.

W kontekście wspomnianego traktatu filozoficznego o szczęściu z lat 1793-1803 należy wymienić osobno list do Dmitrijewa ze stycznia 1798 roku, w którym Karamzin wspomniał o napisaniu w końcu poprzedniego roku jego środkowej części, Rozmowy o szczęściu, a także - niejako wbrew późniejszym interpretatorom, nazywającym te jego dzieła właśnie traktatem filozoficznym — podkreślił swój sceptyczny stosunek do wszelkich teorii filozoficznych ${ }^{44}$. Od stwierdzenia, że życie toczy się zawsze własnym rytmem, za nic mając zdanie filozofów, przechodzi do rozważań o starości i śmierci: bardziej niż na długim życiu, w naturalny sposób skazującym na starość, zależy mu na spokojnej, wolnej od cierpień śmierci. W liście z grudnia 1798 roku zauważył, że boi się nawet myśleć o siwiźnie sześćdziesięciolatka, a jedynym miejscem, w którym gotów byłby spędzić starość, są kraje o cieplejszym niż Rosja klimacie, gdzie mógłby „rozgrzewać zimną krew swoją ciepłem promieni słonecznych"45. W listach pobrzmiewa subtelna ironia, dająca o sobie znać także w jego twórczości literackiej.

Problem szczęścia jest rozpatrywany przez Karamzina bądź w powiązaniu z bieżącymi wydarzeniami politycznymi w Europie, bądź w perspektywie uniwersalnej. Odpowiedź na rewolucję francuską stanowią Melodor do Filaleta i Filalet do Melodora, nazwane przez Łotmana „rozmyślaniami historyczno-politycznymi w dwóch listach"46. Zdaniem Grigorija Makogonienki tytułowe postaci występują nie jako dwie różne osoby, lecz jako ,»głosy duszy« samego Karamzina: to strapiony i zakłopotany Karamzin stary oraz Karamzin nowy, poszukujący nowych, różnych od wcześniejszych, ideałów życiowych, próbujący znaleźć wyjście z sytuacji, która wstrząsnęła całą Europąa"47. Nowa sytuacja nie napawa optymizmem. „O wieku Oświecenia, nie poznaję cię - we krwi i płomieniach nie poznaję cię — pośród zabójstw i zniszczeń nie poznaję cię" — pisze

42 Ibidem, s. 417 (dopisek do listu Sofii).

43 Ю.М. Лотман, Сотворение Карамзина..., s. 298.

${ }^{44}$ Письма Н.М. Карамзина к И.И. Дмитриеву..., s. 91.

45 Ibidem, s. 108.

46 Ю.М. Лотман, Сотворение Карамзина..., s. 227.

${ }^{47}$ Г.П. Макогоненко, Николай Карамзин - писатель, критик, историк, [w:] Н.М. Карамзин, Сочинения в двух томах, t. 1. Автобиография. Письма русского путешественника. Повести, Ленинград 1984, s. 23-24. Рог. Г.П. Макогоненко, Карамзин и Просвещение, [w:] Славянские литературы. VII Международный съезд славистов. Варшава, август 1973 г. Доклады советской делегации, red. М.П. Алексеев, Д.Ф. Марков, А.Н. Робинсон, Москва 1973, s. 304. 
Melodor do Filaleta ${ }^{48}$, a trzykrotnie powtórzone słowa „nie poznaję cię” maksymalnie potęgują wrażenie załamania się dotychczasowej organizacji świata ${ }^{49}$. W odpowiedzi Filaleta, a następnie w ich obszernej (wypełniającej drugą część traktatu) wymianie zdań jest już więcej optymizmu, wiary w człowieka i możliwość osiągnięcia szczęścia. W zamykającym traktat szkicu $O$ najszczęśliwszym okresie życia pisarz porzuca formę dialogu: w odpowiedzi na postawione $\mathrm{w}$ tytule pytanie, konfrontacja różnych postaw oraz aluzje do aktualnych wydarzeń w Europie już przestają być mu potrzebne.

Aby zrozumieć wymowę ostatniej części Karamzinowskiego traktatu filozoficznego o szczęściu, należy zapoznać się z dialogiem Cycerona Katon Starszy o starości, stanowiącym - obok dzieł Arystotelesa, Teofrasta i Demetriosa z Faleronu, Arystona z Keos, Platona, Seneki, Plutarcha i innych — jedną z bardzo licznych wypowiedzi starożytnych myślicieli o starości.

Dialog ten, dedykowany Tytusowi Pomponiuszowi Attykowi, Cyceron napisał z myślą o ,ulżeniu” przyjacielowi i sobie samemu „w znoszeniu [...] ciężaru starości już nieodwołalnie bliskiej albo może już dokuczającej”50. W Leliuszu o przyjaźni, również dedykowanym Attykowi, stwierdził, że napisał go „starzec [...] starcowi" 51 . Cyceron miał wtenczas sześćdziesiąt dwa lata, adresat jego dzieła - o trzy więcej. Katon Starszy wydawał się autorowi wiarygodny jako obrońca starości (taką właśnie wymowę ma praca Cycerona), był bowiem, jak odnotował Tytus Liwiusz, „niemal żelaznej siły ciała i ducha; bo nawet starość, która wszystko kruszy, jego nie złamała" ${ }^{2}$. W Leliuszu o przyjaźni Cyceron napisał, że w dialogu o starości ,przedstawił wykład Katona, ponieważ wydawało [...] się, iż do rozważań o wieku podeszłym nie ma męża stosowniejszego niż ten, który przeżył bardzo długą starość i właśnie jako starzec usuwał innych w cień"53. O tym właśnie, że — parafrazując słowa Tytusa Liwiusza — starość nie wszystko kruszy, traktuje Katon Starszy o starości: autor stara się udowodnić, że, wbrew obiegowym opiniom, nie musi ona nieść z sobą samych trosk i niedogodności: zostają obalone cztery zarzuty wysuwane przeciwko starości, mianowicie że nie

${ }^{48}$ Н.М. Карамзин, Мелодор к Филалету, [w:] idem, Сочинения в двух томах..., t. 2, s. 180.

49 Por. А.В. Предтеченский, Общественно-политические взгляды Н.М. Карамзина в 1790-х годах, [w:] Проблемы русского просвещения в литературе XVIII века, red. П.Н. Берков, Москва-Ленинград 1961, s. 74-75. Badacz przypomina, że pesymistyczny wydźwięk mają także wiersze poety z tego okresu Do Dmitrijewa, Do Aleksandra Aleksiejewicza Pleszczejewa i Do samego siebie (ibidem, s. 74).

${ }^{50}$ Marek Tulliusz Cyceron, Katon Starszy o starości, thum. W. Klimas, oprac. S. Stabryła, Kraków 1995, s. 32.

${ }^{51}$ Marek Tulliusz Cyceron, Leliusz o przyjaźni, tłum. J. Korpanty, Kraków 1997, s. 11.

52 Tytus Liwiusz, Dzieje Rzymu od założenia miasta, t. 5, tłum. M. Brożek, Wrocław 1981, s. 308. Na dowód tego autor podaje następnie, że „mając osiemdziesiąt sześć lat [Katon - M.D.] odpowiadał przed sądem, sam w swej obronie przemawiał i pisał, a w dziewięćdziesiątym roku życia postawił przed sądem ludu Serwiusza Galbę" (ibidem).

${ }^{53}$ Marek Tulliusz Cyceron, Leliusz o przyjaźni..., s. 11. 
pozwala ona na aktywny tryb życia, osłabia ciało, pozbawia zmysłowych przyjemności, wreszcie - że jest bliska śmierci ${ }^{54}$. Jak zauważa Stanisław Stabryła, Katon Starszy o starości ,z zewnętrznego punktu widzenia jest piękną pochwałą starości [...], z drugiej jednak strony trudno byłoby wyobrazić sobie, że Cyceron nie znał złych [...] stron starości, tym bardziej że sam wkroczył już [...] w wiek starczy”: spod jego pióra wyszła więc jednocześnie „pochwała wieku późnego” $\mathrm{i}$,skierowana do samego siebie konsolacja" ${ }^{\text {"s. }}$. Wymowa dzieła Cycerona jest jednak szersza niż to wynika $z$ tytułu, ponieważ przedmiotem rozpatrzenia staje się nie tylko starość, lecz także całe życie człowieka, tak oto charakteryzowane:

bieg życia ludzkiego jest wytyczony, droga natury jest jedna i prosta; w każdym okresie życia człowiek ma inne, właściwe wiekowi cechy: jako dziecko jest nieporadny, w młodości — śmiały i porywczy, w wieku męskim nabiera już powagi, na starość staje się w pełni dojrzały; z tych naturalnych właściwości każdego okresu życia winno się korzystać w swoim czasie $^{56}$.

Szkic $O$ najszczęśliwszym okresie życia Karamzin rozpoczyna od polemiki z Cyceronem. Pisarz rosyjski przyznaje, że staroży tny myśliciel działał — czy raczej oszukiwał — w dobrej wierze: jak można bowiem chwalić starość, skoro idą z nią w parze choroby?; „wbrew Cyceronowi, starość jest smutna” — stwierdza na zakończenie tej części szkicu ${ }^{57}$. O ile Cyceron rozpatrywał starość w czterech aspektach, o tyle Karamzin ogranicza się tylko do jednego, traktując ją jako okres postępującej słabości ciała; albo inaczej: w obronie starości Cyceron sięgał po różnego rodzaju argumenty, od filozoficznych po medyczne, podczas gdy Karamzin w polemice z myślicielem starożytnym skupił się na stronie medycznej. Georges Minois zauważył, że dialog Cycerona rozwijający poglądy Platona na temat starości „umieścić [...] należy raczej w świecie idei, nie zaś w jaskini, w której dogorywają prawdziwi starcy z krwi i kości" ${ }^{58}$. W nawiązaniu do tego spostrzeżenia można zaryzykować twierdzenie, iż w przypadku pisarza rosyjskiego było odwrotnie. To zatem nie starość, ale i nie młodość z charakterystycznymi dla niej popędliwością, zmiennością nastrojów, marzycielskością i nierozwagą uznaje Karamzin za najszczęśliwszy okres w życiu człowieka. Jest nim dojrzałość, gdy, jak pisał, „wszystkie zdolności duchowe działają w swej pełni, a siły fizyczne jeszcze znacząco nie osłabły" ${ }^{59}$. Wiek dojrzały kojarzy się pisarzowi z życiem rodzinnym i społecznym: wychowaniem dzieci, zarządzaniem majątkiem, służbą państwu, kontaktami z przyjaciółmi. Jeżeli więc Cyceron w każdej fazie życia dostrzegał wartość i nawoływał do jej jak najlepszego wykorzystania, to

${ }^{54}$ Zob. K. Kumaniecki, Literatura rzymska. Okres cyceroński, Warszawa 1977, s. 361.

55 S. Stabryła, Wstęp, [w:] Marek Tuliusz Cyceron, Katon Starszy o starości..., s. 18.

56 Marek Tuliusz Cyceron, Katon Starszy o starości..., s. 59-60.

57 Н.М. Карамзин, О счастливейтем времени жизни, [w:] idem, Сочинения в двух mомах..., t. 2, s. 204.

${ }^{58}$ G. Minois, Historia starości. Od antyku do renesansu, thum. K. Marczewska, Warszawa 1995, s. 126.

${ }^{59}$ Н.М. Карамзин, О счастливейшем..., t. 2, s. 204. 
Karamzin wyraźnie wskazywał na jedną z nich. Co charakterystyczne jednak, także w wieku dojrzałym Karamzin wyróżniał fazy rozwojowe, spośród których najwyżej cenił ostatnią, poprzedzającą starość; jak pisał, życie ludzkie jest jak owoc, który najwięcej słodyczy ma wtedy, gdy jest przejrzały, czy jak ostatnie dni jesieni, cieszące przygotowującego się do zimy człowieka bardziej niż pierwsze, dopiero zaczynające tę porę roku. Szkic Karamzina jest zatem również pochwałą, ale pochwałą późnej dojrzałości.

Na zakończenie raz jeszcze warto powrócić do sprawy doboru materiału do badań nad problemem „młodość i starość (według) Karamzina”. O ile wybór korespondencji Karamzina wydaje się oczywisty, o tyle postawienie obok siebie opowieści o Leonie oraz traktatu o szczęściu wymaga dodatkowego komentarza. Rycerz naszych czasów oraz trzy części traktatu dopełniają się wzajemnie nie tylko ze względu na to, że odkrywają Karamzinowską wizję dwóch „skrajnych” okresów życia ludzkiego czy częściowo nawet Karamzinowską koncepcję życia ludzkiego jako takiego. Powiązania między nimi są bowiem głębsze, jakby jeden utwór przygotowywał grunt pod następny. „W Leonie widoczne są cechy [...] Melodora z Rozmowy o szczęściu" — zauważa Koczetkowa ${ }^{60}$. Idąc tym samym tropem, mianowicie odtwarzając koncepcję postaci, nie sposób przeoczyć powtarzania się w nich odwołań do obrazu rycerza: w Rozmowie o szczęściu na słowa Melodora o tym, że „znudziło mu się być Don Kichotem, goniącym za [...] pustym marzeniem”, Filalet odpowiada, iż ,jest to los wszystkich rycerzy naszych czasów"61. Opowieść o Leonie pisarz nie tylko nazwał Rycerz naszych czasów ${ }^{62}$, ale też $\mathrm{w}$ tytule jednego $\mathrm{z}$ rozdziałów wymienił marzycielstwo jako wyróżnik postawy bohatera ${ }^{63}$.

Wychodząc poza dorobek Karamzina, warto dodać, że wypowiedzi o starości pojawiało się na łamach czasopism rosyjskich przełomu XVIII i XIX stulecia więcej. Jednym z nich był opublikowany w piśmie Nikołaja Osipowa „Czto nibud' ot bezdielja na dosugie” w 1800 roku szkic Starość, zawierający rozważania o stosunku do starości starożytnych ${ }^{64}$.

Nikołaj Michajłowicz Karamzin zmarł 22 maja (3 czerwca) 1826 roku w Petersburgu w wieku niespełna sześćdziesięciu lat. Według wyobrażeń starożytnych Rzymian, do których odwoływał się w swojej twórczości, bynajmniej nie umierał jako starzec. W komentarzu do wspomnianych ustępów Leliusza o przyjaźni Cycerona Józef Korpanty przypomniał, że „dla Rzymian starość (senectus) zaczynała się po przekroczeniu sześćdziesiątego roku życia"65.

${ }^{60}$ Н.Д. Кочеткова, ,,Исповедь” в русской литературе..., s. 98.

${ }^{61}$ H.М. Карамзин, Разговор о счастии, [w:] idem, Сочинения в двух томах..., t. 2, s. 190.

62 Por. А.В. Чичерин, Очерки по истории русского литературного стиля. Повествовательная проза и лирика, Москва 1977, s. 73.

63 Por. В.Е. Багно, „Дон Кихот” в России и русское донкихотство, Санкт-Петербург 2009, s. 23-24.

64 Cтарость, „Что нибудь от безделья на досуге” 1800, cz. 5, s. 69-73.

${ }^{65}$ Marek Tulliusz Cyceron, Leliusz o przyjaźni..., s. 76 (przypis). 


\section{Bibliografia}

Bois J.-P., Historia starości. Od Montaigne’a do pierwszych emerytur, tłum. K. Marczewska, Warszawa 1996.

Kumaniecki K., Literatura rzymska. Okres cyceroński, Warszawa 1977.

Marek Tuliusz Cyceron, Katon Starszy o starości, tłum. W. Klimas, oprac. S. Stabryła, Kraków 1995. Marek Tuliusz Cyceron, Leliusz o przyjaźni, tłum. J. Korpanty, Kraków 1997.

Minois G., Historia starości. Od antyku do renesansu, tłum. K. Marczewska, Warszawa 1995.

Postman N., W stronę XVIII stulecia. Jak przeszłość może doskonalić nasza przyszłość, tłum. R. Frąc, Warszawa 2001.

Stabryła S., Wstęp, [w:] Marek Tuliusz Cyceron, Katon Starszy o starości, tłum. W. Klimas, oprac. S. Stabryła, Kraków 1995.

Tytus Liwiusz, Dzieje Rzymu od założenia miasta, t. 5, tłum. M. Brożek, Wrocław 1981.

Багно В.Е., „Дон Кихот” в России и русское донкихотство, Санкт-Петербург 2009.

Вяземский П.А., О письмах Карамзина, [w:] Карамзин: pro et contra. Личность и творчество Н.М. Карамзина в оиенке русских писателей, критиков, исследователей. Антология, red. Д.К. Бурлака, Санкт-Петербург 2006.

Дмитриев И.И., Взгляд на мою жизнь, Москва 1866.

История Лафлёра, Стернова слуги, „Вестник Европы” 1802, июль, nr 13.

Карамзин Н.М., Бедная Лиза, [w:] idem, Записки старого московского жителя. Избранная проза, Москва 1988.

Карамзин Н.М., Избранные статьи и письма, red. А.Ф. Смирнов, Москва 1982.

Карамзин Н.М., О счастливейтем времени жизни, [w:] idem, Сочинения в двух томах, t. 2. Критика. Публицистика. Главы из „Истории Государства Российского”, Ленинград 1984.

Карамзин Н.М., Письма русского путешественника, Ленинград 1984.

Карамзин Н.М., Разговор о счастии, [w:] idem, Сочинения в двух томах, t. 2. Критика. Публицистика. Главы из „Истории Государства Российского”, Ленинград 1984.

[Карамзин Н.М.], Рыцарь нашего времени, „Вестник Европы” 1803, июль, nr 14.

Кочеткова Н.Д., Герой русского сентиментализма. 1. Чтение в жизни „чувствительного” героя, „XVIII век”, t. 14. Русская литература XVIII-начала XIX в. в общественнокультурном контексте, Ленинград 1983.

Кочеткова Н.Д., „Исповедь” в русской литературе XVIII в., [w:] На путях к романтизму, red. Ф.Я. Прийма, Ленинград 1984.

Купреянова Е.Н., Русский роман первой четверти ХІХ века. От сентиментальной повести к роману, [w:] История русского романа в двух томах, t. 1, red. А.С. Бушмин, Б.П. Городецкий, Н.И. Пруцков, Г.М. Фридлендер, Москва 1962.

Лотман Ю.М., Руссо и русская культура XVIII века, [w:] Эпоха Просвещения. Из истории международных связей русской литературы, red. М.П. Алексеев, Ленинград 1967.

Лотман Ю.М., Сотворение Карамзина, [w:] idem, Карамзин. Сотворение Карамзина. Статьи и исследования 1957-1990. Заметки и рецензии, Санкт-Петербург 1997.

Макогоненко Г.П., Карамзин и Просвещение, [w:] Славянские литературы. VII Международный съезд славистов. Варшава, август 1973 г. Доклады советской делегащии, red. М.П. Алексеев, Д.Ф. Марков, А.Н. Робинсон, Москва 1973.

Макогоненко Г.П., Николай Карамзин - писатель, критик, историк, [w:] Н.М. Карамзин, Сочинения в двух томах, t. 1. Автобиография. Письма русского путешественника. Повести, Ленинград 1984.

Макогоненко Г.П., Публицистика, [w:] Н.М. Карамзин, Сочинения в двух томах, t. 2. Критика. Публицистика. Главы из „Истории Государства Российского”, Ленинград 1984.

Муравьев В., Николай Карамзин, Москва 2005.

Slavica Wratislaviensia 163, 2016

(C) for this edition by CNS 
Неизданные сочинения и переписка Николая Михайловича Карамзина, cz. 1, [b. red.], СанктПетербург 1862.

Осетров Е., Три жизни Карамзина. Роман-исследование, Москва 1989.

Переписка Карамзина с Лафатером сообщена доктором Ф. Вальдманом, red. Я. Грот, СанктПетербург 1893.

Письма Н.М. Карамзина к И.И. Дмитриеву, red. Я.К. Грот, П.П. Пекарский, Санкт-Петербург 1866.

Предтеченский А.В., Общественно-политические взгляды Н.М. Карамзина в 1790-е годы, [w:] Проблемы русского просвещения в литературе XVIII века, red. П.Н. Берков, МоскваЛенинград 1961.

Скопкарева С.Л., Структура житийного повествования в произведении Н.М. Карамзина „Рыцарь нашего времени”, [w:] Н.М. Карамзин: писатель, ученый, публицист, red. В.В. Молчановский, С.Н. Травников, Москва 2012.

Старость, „Что нибудь от безделья на досуге” 1800, ч. 5.

Чичерин А.В., Очерки по истории русского литературного стиля. Повествовательная проза и лирика, Москва 1977.

\section{Nikolay Karamzin about (his) youth and old age}

\section{Summary}

The article consists of two parts: 1. Karamzin about (his) youth (Karamzin's letter to J.K. Lavater dated 14 August 1786; A Knight of Our Time — polemic with J. J. Rousseau, similarities and differences between the author's and literary hero's youth), 2. Karamzin about (his) old age (Karamzin's letters to I. Dmitriev dated 1818-1826, V. Karamzin, P. Wiazemski, correspondence of the author's daughters, tractate: Melodor to Filaret, Filaret to Melodor, A conversation about happiness..., On the happiest lifetime - polemic with Cicero's dialogue Cato the Elder On Old Age).

Keywords: youth, old age, happiness, disease, Enlightenment, Nikolay Karamzin, Jean Jacques Rousseau, Marcus Tullius Cicero

\section{Николай Карамзин: (его) молодость и старость}

Резюме

Статья состоит из двух частей: 1 . Молодость Карамзина и по Карамзину (письмо Карамзина И.К. Лафатеру, 14 августа 1786 г.; Рыцарь нашего времени - полемика с Ж.Ж. Руссо, сходства и различия между ранним периодом жизни писателя и литературного героя), 2. Старость Карамзина и по Карамзину (письма Карамзина И. Дмитриеву 1818-1826 гг., В. Карамзину, П. Вяземскому, письма дочерей писателя; трактат: Мелодор к Филалету, Филалет к Мелодору, Разговор о счастии..., О счастливейшем времени жизни - полемика с диалогом Цицерона $O$ старости).

Ключевые слова: молодость, старость, счастье, болезнь, Просвещение, Николай Карамзин, Жан-Жак Руссо, Марк Туллий Цицерон 